\title{
West-strait Regional Tourism: Destination Brand Development Challenges
}

\author{
Junyi Huang \\ Xiamen University Tan Kah Kee College \\ China Merchants Zhangzhou Development Zone \\ Fujian, China 363105
}

\begin{abstract}
The cooperation and competition of China's regional tourism is increasingly clear, as an emerging regional tourism destination, it is imperative to build up the brand if the West-Strait wants to win in the fierce competition in the tourism market. Brand is an effective means of market communication. Branding can help the destination to establish unique brand personality and attractive tourist image, which can have a positive effect on consumers' purchasing behavior. Using the concept and theory of brand marketing, this paper analyzes the necessity and challenge of destination branding, and then to think about the present situation of Fujian tourism brand, in order to promote the strategy formulation and implementation of tourism brand of Fujian, thereby giving impetus to the rise of the West-Strait regional tourism.
\end{abstract}

Keywords-west-strait regional tourism; destination branding; challenge; Fujian province

\section{INTRODUCTION}

The region is the basic characteristic of tourism, which means that the tourism demand, supply and activity have distinct regional. [1]The competition between tourist destinations will be more on the regional level throughout the country and abroad. Therefore, regional tourism development has become one of the hot spots of theoretical research in recent years. The Yangtze River delta, pearl river delta, bohai rim, the central and western regions attract a lot of tourist each year. How can the newly emerging the West-strait region survive and thrive in competition? Building a strong, distinctive brand is one of the keys to success.

Brand creation theory and its practice in other industries is relatively mature, but it is a new field in the destination development, the academic circles are trying to apply marketing and brand theory to regional marketing and regional tourism development. In recent years, many tourist cities have launched tourism theme slogans, but its branding work has only been limited to the theme slogan and logo design. Destination brand creation work, therefore, is increasingly recognized and adopted by destination management organization, but there are many problems in practice which make the brand effect can't get to play, and waste a lot of marketing resources.

This paper selects Fujian province as the research object, and takes the destination brand as the research content, which do not include the research on the tourism enterprise brand.
Fujian province is the main body of the West-strait region tourism, should play a leading role; at present, the West-strait travel website cluster (http://www.fjta.com) is actually the window of Fujian tourism. The propose of West-strait economic zone and its strategic positioning has brought a good opportunity for Fujian tourism development, the Fujian tourism has also identified the strategic target of "construction of the well-known international tourist destination and China's important natural and cultural tourist center"; and pushing the destination branding is an important strategy to achieve the goal. Shaping the West-strait tourism brand is problem needed to be solved urgently by Fujian tourism development in the "twelfth five-year" period.

\section{BRAND AND DESTINATION BRANDING}

\section{A. Brand and Its Function}

The definition of the brand is still divided and can be defined from two perspectives. From the aspect of the suppliers, the brand is used to point to different competitors according to the unique name, description, mark, symbol, image design and their combination of the their products or service. From the aspect of the buyer, it reflects the consumer's perceptions and characteristics, can establish the emotional connection with consumers, so that the brand has an impact on consumer purchasing psychology and control and then the brand owner can get profit that is brand assets.

The above 2 definitions show the two basic functions of a brand. First, the brand can strengthen consumers' perception of products and make it easier for consumers to identify their products from similar products and promote their purchases. Secondly, the brand can establish a unique and attractive image in the consumers' mind, and obtain consumers' preference and loyalty by strengthening the emotional appeal of them, so that increase the product value.

\section{B. Destination Branding}

In tourism research literature, the destination can become a kind of product or perceived as a kind of brand is controversial, but most scholars believe that the destination had all kinds of tangible and intangible characteristics, it contains a lot of different products and services, which will still be regarded as a product by tourists, the only drawback is the destination 
brand creation faces more challenges than tangible products. [2], [3], [4]

In the study of brand management, geographical location or spatial area is gradually considered to be as a brand, which can establish some attractive image like products and people. Nigel Morgan, a British academic who specialist in destination brand research believes that "Destination is taking similar brand technology like that of Coca Cola, Nike, SONY, so that the character can stand out to strengthen its product". Therefore, the relevant concepts and theories of the brand can be extended to the tourism elements and activities - tourist destination. [5]

The domestic tourism industry has entered the stage of branding development, and the criticism on tourism brands have a climax, For example, the country keeps rolling out world heritage sites, national scenic spots and other high-level resources; The media is constantly selecting "the best, the most beautiful, the most desirable, the most popular, the most dynamic" scenic spots. [5]There are successful cases about branding in the international tourism market, such as the developed area of tourism in Spain, Australia, New Zealand, Singapore and New York, Las Vegas and other U.S. cities have shaped more distinctive brand personality.

\section{THE NECESSITY OF THE DESTINATION BRANDING}

\section{A. Fierce Market Competition}

In recent years, China's new tourist destinations have been springing up, and the choice of tourists has become wider, thus the new and the old destinations have become increasingly involved in large-scale marketing campaigns. But many destination appeared similar perception of the image, such as Qingdao, Dalian, Xiamen, Hainan belongs to seaside tourism destination, "glamour, romance, sweet " and word like these are often appeared as the slogan of the tourist city [6], the alternative is stronger, which further exacerbated the market competition.

In the product homogeneity and competitive market, only claim to have the beautiful scenery, unique culture and perfect facilities will no longer have a competitive edge, but must occupy the perception of consumers. Image sensing elements is the key to affect travel decisions, destination branding helps to set up a unique brand personality in visitors mind, and there is close relationship between brand personality and image [4], therefore, a strong brand can occupy the tourist's heart for a long time to affect travel decisions.

\section{B. Experience Tourism Is Coming}

Nowadays, tourists pay more and more attention to the acquisition of tourism experience. First of all, the experience of tourists is difficult to sell, the brand can pack it into easier to market products and services, therefore the tourism destinations should pay more attention to the overall process of the brand.[5] Second, destination choice has become the brand symbol of the lifestyle and bring consumers the core interests, just as the holiday travel can represent a person's identity, way of life and social status, the brand can reflect the consumer characteristics, therefore, the brand may be is the most powerful marketing weapon for the tourism destination marketing personnel [7].

The brand plays a very important role in the consumer purchase decision and evaluation, when the destination needs a new personality or for a new tourist area, such as West-strait tourist area, systematic brand creation is very urgent. China's regional tourism competition is becoming clearer and clearer, and tourism areas such as Yangtze River delta, Pearl River delta and western China are actively seizing the market. As a new regional tourist destination, it is a key step to implement the brand strategy to stand out in the present situation.

\section{DESTINATION BRANDING CHALLENGES}

\section{A. Features of the Destination Product}

The tourism destination provides a kind of service and comprehensive experience relying on the local environment and resources, the destination branding doesn't face the common product, but a kind of service products and local brands. For example, because the invisibility, simultaneity \& heterogeneity of the service, it isn't like tangible products that can be described and displayed easily, which has raised the difficulty and complexity of service brand creation and management.

Second, destination brands often have a strong correlation with regional images. [8] The image of a region is affected by history, politics, economy, natural environment and various emergencies, and it is difficult to maintain consistency and consistency. And these influence factors, many of them are unable to be controlled by the tourism industry, such as malignant social events, major accidents, which impact on the destination brand can be fatal.

\section{B. Obstacles in the Branding Process of the Destination}

Understanding and overcoming obstacles and challenges in branding is the key to successfully create the brand. The obstacles in the branding process of general products also exist in the process of destination branding, and the destination organizations face more challenges in brand marketing. All marketers know that consistency and consistency are the soul of marketing [9], but these two aspects are the biggest challenges of destination branding.

The first is the unity of diversity. The destination branding has to be faced with a number of different characteristics of participants and attractions that make it difficult to maintain consistency in the tourist experience. Like a general enterprise, its product brands can be dominated by an independent organization, but tourism boards have difficulty in dominating the destination products. Different departments of countries, cities and counties, local communities and destinations have a diverse influence on brand decision making and communication due to different perceptions, appeals and powers. Tourism industries like eat, live, travel, tour, shopping, entertainment and so on have provided different products, which respectively adopts different media and means of marketing activities in the different market, thus it is difficult to maintain a consistent brand image. 
The second is the conflict between the long term and the short term. To establish the link among the destination, consumer psychology and social attribute, the destination brand strategy must include a long-term process, however, due to the internal pressure such as short-term economic returns, political interest differences, leading change, it is often changed. [4] Moreover, because of less capital budget, the revenue is not linked to industry development, and it is difficult for a lot of local tourism administration to insist on consistent brand marketing activities for a long time, which has a lot of damage to the destination branding.

\section{TASK OF BRANDING OF THE TOURIST DESTINATION IN FUJIAN}

\section{A. Integrate Multi-destination Brands}

At present, Fujian tourism has only brand products and no brand. Since 1990, Fujian tourism has been devoted to creating brand products, from creating famous scenic spots to promoting thematic routes, as shown in "Table I". However, the destination management organization equates the destination branding with the selection of well-known scenic spots, world heritage and high grade scenic spots, and the understanding of brand concept is biased. These brand products are from around the high-grade tourism resources and cultural characteristics, but because Fujian is lack of the product brand like "charm of Hong Kong, Vientiane", "the very Singapore", the brand products is also difficult to obtain the tourists affective commitment.

In recent years, every city \& scenic area of Fujian collect and launch theme slogan and image identification through all kinds of methods such social collect, various researches of experts, but it is still in the lack of overall theme slogan and logo in Fujian province. As shown in "Table II", the tourism theme slogan of nine cities of Fujian province has distinctive feature rely on their own brand tourism resources, and at present, it is an urgent and arduous task to integrate the brands of West-strait cities such as these nine cities and Meizhou, Wenzhou, Ganzhou and so on.

TABLE I. FUJIAN TOURISM BRAND PRODUCTS

\begin{tabular}{c|l|l}
\hline Year & \multicolumn{2}{c}{ Tourism Brand Products } \\
\hline 1990 & $\begin{array}{l}5 \text { major } \\
\text { brands }\end{array}$ & $\begin{array}{l}\text { Wuyi mountain, Gulangyu, Mazu culture, Yongding } \\
\text { tulou, Hui female amorous feelings }\end{array}$ \\
\hline 2004 & $\begin{array}{l}8 \text { major } \\
\text { brands } \\
\text { Gulangyu, Meizhou Meizu culture,Quanzhou haisi } \\
\text { culture and hui female amorous feelings, Fujian } \\
\text { Tulou, Red tour to the site of Shanghang Gutian, The } \\
\text { ancient cultural relics of Fujian Tanshi mountain, } \\
\text { The wonder of Ningde white water }\end{array}$ \\
\hline \multirow{2}{*}{$\begin{array}{l}1011 \\
\text { major } \\
\text { brands }\end{array}$} & $\begin{array}{l}\text { Happy 6-day tour at Binhai, Essence 8-day tour at } \\
\text { Baimin Mountain, 4-day tour of curiosity of world } \\
\text { heritage, 6-day tour for looking for hometown in } \\
\text { Fujian and Taiwan, 3-day tour of religious culture, 6- } \\
\text { day tour closing to water of northeast of Fujian, 7-day } \\
\text { tour on folk culture exploration, strait tourism - 10 } \\
\text { essence tourism lines in Fujian and Taiwa }\end{array}$ \\
\hline
\end{tabular}

${ }^{\text {a. }}$ Source: Fujian tourism bureau official website.

\section{B. Build and Implement the Destination Brand Strategy}

In 2001, Mr. Ma Yong edited the tourism slogan of "FuTian Fudi Fujian You, MinShan MinShui BaMin You" and the corresponding tourism mark, mascot and a series of tourism image, and but did not get effective enforcement. At present, there is no theme slogan on the website of Fujian tourism window, just showing the pictures of the above brand products. On the 7th strait tourism expo, Zhejiang, Guangdong and other places all can form an integral part of the image perception to tourists, and the Fujian province is to make people feel just like "street vendor" from some counties and cities and scenic spots, which can not attract people due to lack of a consistent overall image.

\section{TABLE II. TOURISM THEME SLOGAN OF 9CITIES OF FUJIAN}

\begin{tabular}{l|l}
\hline \multicolumn{1}{c|}{ 9 Cities } & \multicolumn{1}{c}{ Tourism Theme Slogan } \\
\hline Fuzhou & the ancient capital of hot springs, lucky place \\
\hline Xiamen & War Xiamen, Sea garden \\
\hline Zhangzhou & Shanhai charm, ancient Zhangzhou \\
\hline Quanzhou & $\begin{array}{l}\text { A famous city in the west bank, a multi-cultural treasure } \\
\text { house }\end{array}$ \\
\hline Sanming & mountains \& water spots in Sanming \\
\hline Putian & Hometown of Mazu culture \\
\hline Nanping & $\begin{array}{l}\text { Not decided, beautiful scene ranking 1st on world of Wuyi } \\
\text { Mountain }\end{array}$ \\
\hline Longyan & Hakka style, green affection, red charm \\
\hline Ningde & $\begin{array}{l}\text { Not decided, emphasizes the landscape and geological } \\
\text { wonders of the mountains }\end{array}$ \\
\hline \multicolumn{1}{c}{ b. Source: The official website of the 9 cities and Fujian tourism bureau. }
\end{tabular}

A successful brand strategy must fully demonstrate the elements of name, description, markup, symbol, image design, etc., and these elements are surrounded with a clear and distinctive theme. The Fujian tourism brand image decided in tourism plan has not been enough announced, since then there is no new theme slogan, other brand elements are not perfect, and no more activities on integration. Therefore, the second task of the brand of tourism destination in Fujian is to focus on the theme, design and integrate the brand elements, and publicize the whole and consistent image.

A unified brand image has been created, and however, if the related departments and tour operators are unable to maintain a consistent brand experience during the actual travel process, it is meaningless to do the branding. Because the establishment of a strong brand can not only rely on advertising, but more rely on brand experience. Therefore, it is more difficult to identify and maintain brand identity among tourism management agencies and various tourism enterprises. To this end, the third task of the branding of Fujian tourism destination is to overcome the pressure and obstacles, and to manage the brand in terms of the long-term vision and consistent action from the marketing communication and the tourist experience.

\section{CONCLUSION}

The competition of tourist destination will become increasingly fierce, so the destination brand work is urgent. As tourism demand, supply and activity have distinct regional features, the competition between tourist destinations will be more at the regional level. However, the concept and 
technology of the brand are applied to tourism development for a short time. According to the concept of the brand and the research achievements of tourist destination brand, this paper puts forward the West-strait regional tourism brand challenging due to the particularity of tourist destination brand, and the difficulty of the destination brand consistency and coherence. The subject and organizers of West-strait regional tourism are tourism in Fujian province, this paper collects and analyzes tourism foreign brand publicity materials of the nine cities of Fujian province, and found that Fujian only have tourism brand products without brand, and the tourism theme slogan is not unified. Based on the above research, this paper puts forward two tasks on the tourism brand of Fujian: to further refine a touching and predictable theme slogan, then, public it as a whole image. In addition, it is also important to control and manage the brand experience of tourism and tourism enterprises.

\section{REFERENCES}

[1] Ge Licheng, Nie Xiezhong Regional tourism corporation - Theoretical analysis and case study [M].Beijing: Social sciences press, 2009.21-23.

[2] Sun-Young Park and James F. Petrick.Destinations' Perspectives of Branding[J].Annals of Tourism Research, 2006,33 (1):262-265.

[3] Gnoth.J.Leveraging export brands through a tourism destination brand[J].Band Management, 2002,9 (4-5):262-280.

[4] Metin Kozak and Seyhmus Baloglu.Managing and marketing tourist destinations : strategies to gain a competitive edge [M].New York : Routledge, 2011: 155-193.

[5] Li Jinglong. Brand tourism resources and development[M]. Hefei: Anhui University Press, 2010.27-31.

[6] Qu Ying, Li Tianyuan.Evaluation on positioning the theme slogan based on the tourism destination brand management process - Take China's excellent tourist city as an example [J]. Travel journal, 2008,23(1):3035.

[7] Nigel Morgan, Annette Pritchard.Meet the challenge of brand management of tourist destination [A]. Nigel Morgan ETC..Travel destination brand management[C]. Tianjin: Nankai University Press, 2006.63-85.

[8] Simon Anhol.National brand and origin value [A]. Niegel Morgan etc.. Travel destination brand management [C]. Tianjin: Nankai University Press, 2006.27.

[9] Wally Olins. National brand creation: Angle of history [A]. Nigel Morgan etc.. Travel destination brand management [C]. Tianjin: Nankai University Press, 2006.20. 